\title{
CYTOTOXIC AND ANTIMICROBIAL XANTHONES FROM Cratoxylum arborescens (Guttiferae)
}

\section{Maizatul Akmal Yahayu ${ }^{1}$, Mawardi Rahmani*1, Najihah Mohd Hashim², Gwendoline Cheng Lian Ee ${ }^{1}$, Mohd Aspollah Sukari ${ }^{1}$ and Abdah Md Akim ${ }^{3}$}

${ }^{1}$ Department of Chemistry, Universiti Putra Malaysia, 43400 UPM, Serdang, Selangor, Malaysia

${ }^{2}$ Department of Pharmacy, University of Malaya, 50603 Kuala Lumpur, Malaysia

${ }^{3}$ Department of Biomedical Science, Universiti Putra Malaysia, 43400 UPM, Serdang, Selangor, Malaysia

\begin{abstract}
Phytochemical and biological studies were carried out the stem bark of Cratoxylum arborescens collected from Sarawak, Malaysia. Chromatographic separation of the plant extracts led to the isolation of three xanthones, $\alpha$-mangostin (1), $\beta$-mangostin (2) and fuscaxanthone $\mathrm{C}(\mathbf{3})$ together with the commom stigmasterol. The structural elucidation of the compound was determined by detail spectroscopic analysis and comparison with literature reports. $\alpha$-Mangostin exhibited strong inhibition on the growth of bacteria, B. subtilis, B. cereus, S. typhimurium and S. aureus with inhibition zone of 16, 20, 17 and $20 \mathrm{~mm}$, respectively. Both $\alpha$-mangostin and $\beta$-mangostin showed the most significant cytotoxic activity against MCF7 cells with $\mathrm{IC}_{50}$ values of $12.48 \mu \mathrm{g} / \mathrm{ml}$ and $28.42 \mu \mathrm{g} / \mathrm{ml}$, respectively. However, when tested for antioxidant activity by using DPPH, the extracts and the xanthones failed to give good results.
\end{abstract}

(Keywords: $\alpha$-Mangostin; $\beta$-Mangostin; Fuscaxanthone C; Cratoxylum arborescens; Antimicrobial; Cytotoxicity; Antioxidant )

\section{INTRODUCTION}

Cratoxylum is a genus of small to medium size trees under the Guttiferae family found mainly in peat and fresh water swamps in Southeast Asia to Celebes and Philippines [1]. Cratoxylum species is well known for their strong and durable wood and the stem barks normally exuded orange, yellow or reddish resinous sap which turns black when dried [2]. Some species were used by the local communities for their diuretic and tonic effect for the treatment of stomach ache, fevers, coughs, diarrhea, itches, ulcers, food poisoning and internal bleeding [3, 4]. Cratoxylum arborescens locally known as "geronggang" or "serungan" in Sabah and "dat" in Sarawak has been found suitable for making veneers, plywood, flooring, interior works and light to medium construction [5]. They are also used as ornamental plants as well as for slope protection. The chemical constituents on Cratoxylum species is not well studied and previous reports indicated the species are a good source of oxygenated and prenylated xanthones, anthraquinones, flavonoids and sterols [6-9]. In addition there has been not much work being reported on the bioactivity of the species as well as their constituents. In this communication we report the identification of three xanthones from Cratoxylum arborescens together with antimicrobial, cytotoxicity and antioxidant activities of the extracts and pure compounds.

\section{MATERIAL AND METHODS}

\section{General experimental procedure}

Melting points were determined on a Leica Galen III apparatus. UV spectra were determined in EtOH using a Shimadzu UV-160A spectrophotometer. NMR spectra were obtained with a JEOL JNM-CRX $500 \mathrm{MHz}$ FT-NMR spectrometer in acetone- $d_{6}$ as solvent and tetramethylsilane as internal standard. IR spectra were obtained using a Perkin Elmer FTIR model 1725X spectrometer. EIMS were recorded on a Shimadzu GCMS-QP5050A spectrometer. Silica gel $60 \mathrm{H} 1.07736$ Merck and $60(0.063-0.200$ mm) 1.07734 Merck were used for column chromatography. Precoated sheets of silica gel $60 \mathrm{~F}_{254}$ Merck were used for TLC analysis and the spots were visualized either with a UV lamp ( $254 \mathrm{~nm}$ and $356 \mathrm{~nm}$ ) or by iodine vapor.

\section{Extraction and isolation of compounds}

The plant material was collected Sibu, Sarawak in 2007. The ground air-dried stem bark of Cratoxylum arborescens $(1.0 \mathrm{~kg})$ was sequentially extracted by cold percolation with hexane, chloroform and methanol to give 6.12, 
28.18, and $40.27 \mathrm{~g}$ of dark viscous semisolid materials after solvents removal, respectively. The hexane extract $(5.5 \mathrm{~g})$ was separated by vacuum column chromatography and eluted with mixtures of solvents, hexane/chloroform, chloroform/ethyl acetate and ethyl acetate/methanol to give 25 fractions of $200 \mathrm{ml}$ each. Similar fractions based on TLC and observed under UV light were combined. Fractions 11-13 were further separated by mini column chromatography to give the common stigmasterol as white needles. Fractions 17-21 were similarly further separated by column chromatography to yield yellow solid and recrystallised with chloroform as yellowish powder of $\beta$-mangostin (2) with m.p. $163-164^{\circ} \mathrm{C}$. Similar fractionation of the chloroform extract with series of column chromatography led to the isolation another batch of $\beta$-mangostin (2) and $\alpha$-mangostin (1) with m.p. $178-180^{\circ} \mathrm{C}$. From the separation of the methanol extract, another batch of $\alpha$-mangostin (1) and fuscaxanthone $\mathrm{C}$ (3) were obtained.

\section{Antimicrobial activity}

Disc diffusion method with a slight modification was used to determine antimicrobial activities of the samples [10]. The seven bacterial stock cultures Bacillus subtilis, Bacillus cereus, Escherichia coli, Klebsiella pneumonia, Salmonell typhimurium Staphylococcus aureus and Enterobacter aerogenes were stored at $4{ }^{\circ} \mathrm{C}$ and maintained on nutrient agar. The lone fungal culture Candida albican was maintained on potato dextrose agar. The microbes were cultured in appropriate broths at $30^{\circ} \mathrm{C}$ overnight and the concentrations of the broth were adjusted turbidometrically at wavelength of $600 \mathrm{~nm}$ to give $10^{5}-10^{6}$ colony forming units per $\mathrm{ml}$. The crude extracts and pure compounds were dissolved in DMSO at concentration of 10 and $1 \mathrm{mg} / \mathrm{ml}$, respectively. $10 \mu \mathrm{l}$ each of the samples were loaded on Whatman No. 1 filter paper disc $(6 \mathrm{~mm})$. The disc was placed on the surface of the agar plate previously inoculated with $0.1 \mathrm{ml}$ suspension of each microorganism. The agar plates were then inverted and incubated for 24 hours at $30^{\circ} \mathrm{C}$. The antimicrobial activity was recorded by measuring the zone of inhibition (in $\mathrm{mm}$ ) around each disc. Each test was done in duplicate. Antibiotics tetracycline and ampicillin (10 $\mu \mathrm{g} / \mathrm{ml}$ ) were used as positive control for bacterial test, while nystatin (100 IU/disc) as a positive control for antifungal test. Negative control used in the assay was DMSO.

\section{Cytotoxic Assay}

Human breast adenocarcinoma cancer (MCF7) cell line obtained from RIKEN Cell Bank, Tsukuba, Japan was used in the experiment. The cells were grown and maintained in RPMI 1640 (Sigma, USA) medium supplemented with $10 \%$ fetal bovine serum (Flow Lab., Australia), 100 IU/ml penicillin (Flow Lab., Australia) and 100 $\mathrm{g} / \mathrm{ml}$ streptomycin (Flow Lab., Australia) at $37^{\circ} \mathrm{C}, 5 \% \mathrm{CO}_{2}$ and $90 \%$ humidity. Microculture Tetrazolium Salt (MTT) assay [11] was used to screen the cytotoxic activity of the crude extracts and pure compounds. The stock solution of crude extracts and pure compounds were prepared at the concentration of $10 \mathrm{mg} / \mathrm{ml}$ and $1 \mathrm{mg} / \mathrm{ml}$ in DMSO, respectively. Cytotoxic assays were performed in 96-flat bottom microwell plates and each well was filled with $100 \mu \mathrm{l}$ of exponentially growing cell suspension in complete growth medium at the concentration of $5 \times 10^{5}$ cells/ ml. The untreated cells were used as control and the assays were performed in triplicate. The culture plates were incubated for 3 days at $37^{\circ} \mathrm{C}, 5 \%$ $\mathrm{CO}_{2}$ and $90 \%$ humidified incubator. The fractions of surviving cells were determined 3 days after incubation relatively to the untreated cell population by the colorimetric MTT (3-[4,5dimethyl-thiazol-2-yl]-2,5-diphenyltetrazolium bromide) assay. The viability of cells was determined by measuring the amount of blue formazan crystal formed after the freshly prepared $20 \mu \mathrm{l}$ of MTT solution (5mg in $1 \mathrm{ml}$ PBS) was added to each well followed by 4 hours incubation at $37^{\circ} \mathrm{C}$. Then $100 \mu \mathrm{l}$ of DMSO was added to each well and mixed thoroughly by pipetting 10-20 times to dissolve the blue formazan crystals. The plate was then left at room temperature for 30 minutes and the absorbance (OD) of each well was measured at $570 \mathrm{~nm}$ and the reference $630 \mathrm{~nm}$ wavelength by using microplate reader. The cells were killed by cytotoxic agent resulted the less formazan production and lower OD. The percentage of cell viability was determined as follows:

$$
\% \text { Viability }=\quad \frac{\mathrm{OD}}{\mathrm{OD}} \underset{\text { control }}{\text { sample }} \times 100 \%
$$

A graph was plotted for the percentage of cell viability against concentration of the extracts or compounds and the cytotoxic index used was $\mathrm{IC}_{50}$, the concentration that yield $50 \%$ inhibition of the cell compared with untreated control. 


\section{DPPH Free Radical Scavenging Activity}

The assay was carried out by using 96 microwell plates. A solution of DPPH (1,1-diphenyl-2picrylhydrazine) (5 $\mathrm{mg})$ was prepared by dissolving in DMSO (2 ml) and the solution was kept in the dark at $4^{\circ} \mathrm{C}$. A stock solution of the crude extracts and compounds was prepared in methanol $(1 \mathrm{mg} / \mathrm{ml})$. The positive standard used in this assay was $\alpha$-tocopherol (Sigma, USA). The stock solution $(500 \mu \mathrm{g} / \mathrm{ml})$ was serially diluted (two fold dilution) in the 96 micro-well plates to varying concentrations. Then DPPH solution $(5 \mu \mathrm{l})$ was added to each well and the plate was shaken to ensure thorough mixing before being placed in the dark by wrapping it with aluminium foil. After 30 minutes, the optical density of the well was read using ELISA Reader (Biotek $\mu$-quant Instrumentation) at wavelength $517 \mathrm{~nm}$. The percentage inhibition was calculated using the following formula:

$\%$ Inhibition $=1-\mathrm{OD}(\mathrm{DPPH}+$ Sample $) / \mathrm{OD}$ (DPPH + DMSO) $\times 100$

The $\mathrm{IC}_{50}$ value was determined as the concentration of each sample required to give $50 \%$ of the optical density shown by the control. All tests and analyses were run in triplicate and averaged.

\section{RESULTS}

Individual separation of the hexane, chloroform and methanol extracts by various chromatographic techniques led to the isolation of three xanthones $\alpha$-mangostin (1), $B$-mangostin (2) and fuscaxanthone $\mathrm{C}(\mathbf{3})$ together with the common stigmasterol. $\alpha$-Mangostin (1) was recrytallised in hot chloroform to yield fine yellow crystal with m.p $178-180^{\circ} \mathrm{C}$ ([12] m.p. $181-182^{\circ} \mathrm{C}$ ), highly soluble in acetone and showed the following spectral data: UV $(\mathrm{MeOH})$ $\lambda_{\max } \mathrm{nm}(\log \varepsilon): 390$ (2.41), 358 (3.99), 316 (3.99) and 238 (2.65); IR $v_{\max } \mathrm{cm}^{-1}$ (KBr): 3369, 2934, 1648, 1608, 1462 and 1286; EIMS $\mathrm{m} / \mathrm{z}(\%$ intensity): 410 (43), 395 (6), 379 (2), 354 (26), 339 (100), 311 (33), 296 (13), 285 (19), 257 (6) and $162(14) ;{ }^{1} \mathrm{H}-\mathrm{NMR}\left(500 \mathrm{MHz}\right.$, acetone- $\left.d_{6}\right)$ and ${ }^{13} \mathrm{C}$-NMR $\left(125 \mathrm{MHz}\right.$, acetone- $\left.d_{6}\right)-$ see Table 1. Compound (2) was obtained as yellow powder with melting point $163-164^{\circ} \mathrm{C}$ ([13] m.p $162-165^{\circ} \mathrm{C}$ ) and exhibited the following spectral data: UV (MeOH) $\lambda_{\max } \mathrm{nm}(\log \varepsilon): 374$ (1.89), 350 (3.99), 344 (2.19), and 340 (3.29); IR $v_{\max }$ $\mathrm{cm}^{-1}$ (KBr): 3407, 2923, 1642 and 1596; EIMS m/z (\% intensity): 424 (54), 409 (5), 393 (2), 3.81 (19), 368 (32), 353 (100), 335 (21), 310 (8), 299 (24) and 169 (8); ${ }^{1} \mathrm{H}-\mathrm{NMR}(500 \mathrm{MHz}$, acetone- $\left.d_{6}\right)$ and ${ }^{13} \mathrm{C}-\mathrm{NMR}(125 \mathrm{MHz}$, acetone$d_{6}$ ) - see Table 1. Fuscaxanthone C (3) was isolated from the methanol extract of as yellow oil easily dissolved in chloroform with the following spectral data: IR $v_{\max } \mathrm{cm}^{-1}(\mathrm{KBr})$ : 3397, 2927, 1644, 1598 and 1460; EIMS $\mathrm{m} / \mathrm{z}$ (\% intensity): 438 (58), 423 (5), 383 (53), 367 (100), 351 (38), 339 (46), 313 (21) and $176(24)$; ${ }^{1} \mathrm{H}-$ NMR $\left(500 \mathrm{MHz}\right.$, acetone- $\left.d_{6}\right)$ and ${ }^{13} \mathrm{C}-\mathrm{NMR}$ (125 MHz, acetone- $\left.d_{6}\right)$ - see Table 1.

The three extracts were moderately active against five of the bacterial strains and inactive towards two of the bacteria and the lone fungus (Table 2). $\alpha$-Mangostin (1) exhibited strong inhibition on the growth of B. subtilis, B. cereus, $S$. typhimurium and $S$. aureus. In comparison, $\beta$ mangostin (2) was found moderately active against these bacterial strains. The cytotoxic activity of the crude extracts and pure compounds are summarized in Table 3. For the free radical DPPH scavenging activity, the extracts and the pure compounds failed to exhibit antioxidant activity.

\section{DISCUSSION}

Mangostin (1) was obtained as fine yellow crystal with m.p $178-180^{\circ} \mathrm{C}$ and the mass spectrum gave a molecular ion peak at $m / z 410$ which corresponded to molecular formula $\mathrm{C}_{24} \mathrm{H}_{26} \mathrm{O}_{6}$. The absorptions at 390, 358, 316 and $238 \mathrm{~nm}$ in the UV spectrum are the typical characteristic of 1,3,6,7-tetraoxygenated xanthone. The IR spectrum revealed the existence of hydroxyl and carbonyl functionalities with prominent peaks at 3369 and $1648 \mathrm{~cm}^{-1}$, respectively. The ${ }^{1} \mathrm{H}-\mathrm{NMR}$ spectrum displayed the presence of a chelated hydroxyl group with the occurrence of a very low field signal at $\delta 13.79$ and a methoxy group at $\delta 3.78$ as a sharp singlet (Table 1 ). Two singlets at $\delta$ 6.81 and $\delta 6.38$ were assigned to the two isolated aromatic protons at position $\mathrm{C}-5$ and $\mathrm{C}-4$, respectively. The presence of two prenyl side chains were validated by the following characteristic signals; the two doublet at $\delta 4.12$ $(J=6.8 \mathrm{~Hz})$ and $\delta 3.35(J=8.0 \mathrm{~Hz})$ were assigned to benzylic methylene groups at $\mathrm{C}-1$ ' and C-1", respectively. A triplet at $\delta 5.26$ which integrated to two protons was due to overlapped vinylic protons at C-2' and C-2". Two methyl groups at $\delta 1.82$ and $\delta 1.71$ together with another 
Table 1. ${ }^{1} \mathrm{H}-\mathrm{NMR}\left(500 \mathrm{MHz}\right.$, acetone- $\left.d_{6}\right)$ and ${ }^{13} \mathrm{C}-\mathrm{NMR}\left(125 \mathrm{MHz}\right.$, acetone- $\left.d_{6}\right)$ spectral data of $\alpha$-mangostin $(\mathbf{1})$, $\beta$-mangostin $(\mathbf{2})$ and fuscaxanthone C (3)

\begin{tabular}{|c|c|c|c|c|c|c|c|c|}
\hline \multirow[t]{2}{*}{ Carbon } & \multicolumn{3}{|c|}{ (1) } & \multicolumn{3}{|c|}{ (2) } & \multicolumn{2}{|l|}{ (3) } \\
\hline & $\delta_{\mathrm{H}}$ & $\delta_{\mathrm{C}}$ & HMBC & $\delta_{\mathrm{H}}$ & $\delta_{\mathrm{C}}$ & HMBC & $\delta_{\mathrm{H}}$ & $\delta_{\mathrm{C}}$ \\
\hline 1 & $13.79(\mathrm{OH}, 1 \mathrm{H}, s)$ & 160.9 & $\mathrm{C}_{9 \mathrm{a}}, \mathrm{C}_{2}, \mathrm{C}_{1}$ & $13.61(\mathrm{OH}, 1 \mathrm{H}, s)$ & 164.4 & $\mathrm{C}_{9 \mathrm{a}}, \mathrm{C}_{2}, \mathrm{C}_{1}$ & $13.47(\mathrm{OH}, 1 \mathrm{H}, \mathrm{s})$ & 159.7 \\
\hline 2 & - & 110.2 & - & - & 115.7 & - & - & 111.2 \\
\hline 3 & $9.52(\mathrm{OH}, 1 \mathrm{H}, s)$ & 154.9 & - & - & 160.1 & - & - & 163.8 \\
\hline 4 & $6.38(1 \mathrm{H}, s)$ & 92.3 & $\mathrm{C}_{9 \mathrm{a}}, \mathrm{C}_{2}, \mathrm{C}_{4 \mathrm{a}}, \mathrm{C}_{10 \mathrm{a}}$ & $6.47(1 \mathrm{H}, s)$ & 93.8 & $\mathrm{C}_{9 \mathrm{a}}, \mathrm{C}_{2}, \mathrm{C}_{4 \mathrm{a}}, \mathrm{C}_{10 \mathrm{a}}$ & $6.33(s, 1 \mathrm{H}, \mathrm{s})$ & 89.0 \\
\hline $4 a$ & - & 162.1 & - & - & 168.5 & - & - & 155.4 \\
\hline 5 & $6.81(1 \mathrm{H}, s)$ & 101.9 & $\mathrm{C}_{8 \mathrm{a}}, \mathrm{C}_{7}, \mathrm{C}_{6}$ & $6.82(1 \mathrm{H}, s)$ & 106.6 & $\mathrm{C}_{8 \mathrm{a}}, \mathrm{C}_{7}, \mathrm{C}_{6}$ & $6.74(s, 1 \mathrm{H})$ & 98.8 \\
\hline 6 & $9.62(\mathrm{OH}, 1 \mathrm{H}, s)$ & 155.4 & - & $9.62(\mathrm{OH}, 1 \mathrm{H}, s)$ & 160.2 & - & - & 158.8 \\
\hline 7 & - & 143.6 & - & - & 148.5 & - & - & 144.4 \\
\hline 8 & - & 137.3 & - & - & 142.0 & - & - & 136.5 \\
\hline $8 \mathrm{a}$ & - & 111.2 & - & - & 115.9 & - & - & 111.5 \\
\hline 9 & - & 182.0 & - & - & 186.8 & - & - & 182.2 \\
\hline $9 \mathrm{a}$ & - & 102.8 & - & - & 108.0 & - & - & 103.5 \\
\hline $10 \mathrm{a}$ & - & 156.6 & - & - & 161.5 & - & - & 155.5 \\
\hline $1 ’$ & $4.12(1 \mathrm{H}, d, 6.8)$ & 26.1 & $\mathrm{C}_{7}, \mathrm{C}_{8}, \mathrm{C}_{2}, \mathrm{C}_{3}, \mathrm{C}_{8 \mathrm{a}}$ & $4.10(1 \mathrm{H}, d, 6.8)$ & 30.8 & $\mathrm{C}_{7}, \mathrm{C}_{8}, \mathrm{C}_{2}, \mathrm{C}_{3}, \mathrm{C}_{8 \mathrm{a}}$ & $3.36(d, J=6.9 \mathrm{~Hz})$ & 21.1 \\
\hline 2 ' & $5.26(2 \mathrm{H}, t, 6.8)$ & 123.9 & $\mathrm{C}_{4}, \mathrm{C}_{5}$ & $5.25(2 \mathrm{H}, t, 6.8)$ & 128.6 & $\mathrm{C}_{4}, \mathrm{C}_{5}$ & $5.25(t, J=4.6 \mathrm{~Hz})$ & 122.5 \\
\hline $3^{\prime}$ & - & 130.6 & - & - & 135.4 & - & - & 130.8 \\
\hline $4^{\prime}$ & $1.82(3 \mathrm{H}, s)$ & 17.5 & - & $1.80(3 \mathrm{H}, s)$ & 22.2 & - & $1.79(s, 3 \mathrm{H})$ & 17.1 \\
\hline 5 & $1.64(3 \mathrm{H}, s)$ & 25.1 & - & $1.63(3 \mathrm{H}, s)$ & 29.8 & - & $1.67(s, 6 \mathrm{H})$ & 25.1 \\
\hline $1 ”$ & $3.35(2 \mathrm{H}, d, 8.0)$ & 21.1 & $\mathrm{C}_{2}, \mathrm{C}_{2^{\prime \prime}}, \mathrm{C}_{3^{\prime \prime}}$ & $3.29(2 \mathrm{H}, d, 6.9)$ & 25.8 & $\mathrm{C}_{18}, \mathrm{C}_{17}, \mathrm{C}_{2}$ & $4.14(d, J=6.9 \mathrm{~Hz})$ & 25.9 \\
\hline $2 "$ & $5.26(2 \mathrm{H}, t, 8.0)$ & 122.6 & $\mathrm{C}_{4}, \mathrm{C}_{5}, \mathrm{C}_{2}$ & $5.18(2 \mathrm{H}, t, 6.9)$ & 127.2 & $\mathrm{C}_{4}, \mathrm{C}_{5}, \mathrm{C}_{2}$ & $5.25(t, J=4.6 \mathrm{~Hz})$ & 123.8 \\
\hline $3 ”$ & - & 130.6 & - & - & 135.4 & - & - & 130.7 \\
\hline $4 "$ & $1.71(3 \mathrm{H}, s)$ & 17.1 & - & $1.75(3 \mathrm{H}, s)$ & 21.7 & - & $1.84(s, 3 \mathrm{H})$ & 17.5 \\
\hline 5 & $1.64(3 \mathrm{H}, s)$ & 25.1 & - & $1.61(3 \mathrm{H}, s)$ & 29.8 & - & $1.67(s, 6 \mathrm{H})$ & 25.2 \\
\hline 3-OMe & - & - & & $3.94(3 \mathrm{H}, s)$ & 60.4 & - & $3.90(s, 3 \mathrm{H}, \mathrm{s})$ & 55.8 \\
\hline 6-OMe & - & - & - & - & - & & $3.96(s, 3 \mathrm{H})$ & 55.9 \\
\hline 7-OMe & $3.78(3 \mathrm{H}, s)$ & 62.5 & - & $3.77(3 \mathrm{H}, s)$ & 65.2 & - & $3.79(s, 3 \mathrm{H})$ & 60.2 \\
\hline
\end{tabular}


Table 2. Inhibition zone (in $\mathrm{mm}$ ) of antimicrobial activity of crude extracts of Cratoxylum arborescens, $\alpha$ mangostin and $\beta$-mangostin

\section{Diameter of inhibition zone in $\mathbf{m m}$}

\begin{tabular}{|c|c|c|c|c|c|c|c|c|c|}
\hline Plant species & Extract & $\begin{array}{l}\text { B. } \\
\text { subtilis }\end{array}$ & $\begin{array}{l}\text { B. } \\
\text { cereus }\end{array}$ & $\begin{array}{l}\text { E. } \\
\text { coli }\end{array}$ & $\begin{array}{l}\text { K. } \\
\text { pneumonia }\end{array}$ & $\begin{array}{l}\text { S. } \\
\text { typhimurium }\end{array}$ & $\begin{array}{l}S . \\
\text { aureus }\end{array}$ & $\begin{array}{l}\text { E. } \\
\text { aerogenes }\end{array}$ & $\begin{array}{l}\text { C. } \\
\text { albican }\end{array}$ \\
\hline \multirow{3}{*}{$\begin{array}{l}\text { Cratoxylum } \\
\text { arborescens }\end{array}$} & Hexane & 9 & 10 & - & - & 9 & 8 & 7 & - \\
\hline & $\mathrm{CHCl}_{3}$ & 10 & 10 & - & - & - & 9 & - & - \\
\hline & $\mathrm{MeOH}$ & 10 & 8 & - & - & 7 & - & 8 & - \\
\hline$\alpha$-Mangostin (1) & - & 16 & 20 & - & - & 17 & 20 & - & - \\
\hline $\begin{array}{l}\beta \text {-Mangostin } \\
(2)\end{array}$ & - & 7 & 9 & - & - & 11 & 11 & - & - \\
\hline Tetracycline & - & 27 & 25 & 25 & 21 & 24 & 21 & 24 & \\
\hline Ampicillin & - & 10 & 10 & 25 & - & 28 & 23 & 16 & \\
\hline Nystatin & - & & & & & & & & 23 \\
\hline
\end{tabular}

Note: (-) not active, tetracycline and ampicillin $10 \mu \mathrm{g} / \mathrm{ml}$, nystatin $100 \mathrm{IU} /$ disc.

Table 3. Antioxidant and cytotoxic activity of crude extracts of Cratoxylum arborescens, $\alpha$-mangostin and $\beta$-mangostin arborescens.

\begin{tabular}{llcc}
\hline Species/ pure compound & Crude extract & DPPH $\left(\mathbf{I C}_{\mathbf{5 0}}(\boldsymbol{\mu g} / \mathbf{m l})\right)$ & MCF7 $_{\left(\mathbf{I C}_{\mathbf{5 0}}(\boldsymbol{\mu g} / \mathbf{m l})\right.}$ \\
\hline & & $>500$ & $>30$ \\
\hline Cratoxylum arborescens & Hexane & $>500$ & $>30$ \\
\hline & $\mathrm{CHCl}_{3}$ & 102.5 & $>30$ \\
\hline & $\mathrm{MeOH}$ & $>500$ & 12.48 \\
\hline$\alpha$-Mangostin $(\mathbf{1})$ & - & $>500$ & 28.42 \\
\hline B-Mangostin $(2)$ & - & & \\
\hline & & $<7.8$ & - \\
\hline$\alpha-$ Tocopherol & - & - & 0.2 \\
\hline Doxorubicin & - & &
\end{tabular}

two overlapped methyl groups at $\delta 1.64$ disclosed their presence at positions H-4', H-4", $\mathrm{H}-5$ ' and H-5". The ${ }^{13} \mathrm{C}-\mathrm{NMR}$ and DEPT spectra displayed twenty-four signals corresponded to four methyl, one methoxyl, two methylene, four methine and twelve quarternary carbons and one carbonyl carbon $(\delta$ 182.0). All protonated carbons were assigned based on the HMQC spectrum. The HMBC spectrum analysis revealed the position of attachments of various side chains to the xanthone skeleton as can be seen by the ${ }^{2} J$ and ${ }^{3} J$ correlations of methylene protons at $\mathrm{H}-1$ ' to $\mathrm{C}-7, \mathrm{C}-8, \mathrm{C}-2$ ', $\mathrm{C}-3$ ' and $\mathrm{C} 8 \mathrm{a}$ as well as at $\mathrm{H}-1$ " to $\mathrm{C}-2, \mathrm{C}-2$ " and $\mathrm{C}-3$ ". Based on these data and comparison with literature reports, the compound was identified as $\alpha$ - mangostin (1) previously isolated from Garcinia mangostana [12].

$\beta$-Mangostin (2) was obtained as yellow powder with melting point $163-164^{\circ} \mathrm{C}$. The EIMS spectrum showed the molecular ion peak at $\mathrm{m} / \mathrm{z}$ 424 in agreement with the molecular formula $\mathrm{C}_{25} \mathrm{H}_{28} \mathrm{O}_{6}$ which is 24 mass unit higher than compound (1). The UV absorption bands at $\lambda_{\max }$ $374,350,344$ and $340 \mathrm{~nm}$ were the typical characteristic of xanthone skeleton. The IR spectrum revealed a broad absorption band at $3407 \mathrm{~cm}^{-1}$ of the hydroxyl group and a strong absorption at $1642 \mathrm{~cm}^{-1}$ for the presence of a highly chelated carbonyl function. The ${ }^{1} \mathrm{H}-\mathrm{NMR}$ and ${ }^{13} \mathrm{C}-\mathrm{NMR}$ spectral data of compound (2) were quite similar to $\alpha$-mangostin (1) but with a 
notable difference on the replacement of the hydroxyl group at C-3 by the methoxyl group (Table 1). The ${ }^{1} \mathrm{H}-\mathrm{NMR}$ spectrum indicated the occurrence of twenty-eight protons with one chelated hydroxyl group at low field region of $\delta$ 13.61. The two prenyl side chains displayed similar characteristic resonances as in compound (1) which strongly suggested their attachment to the xanthone skeleton through $\mathrm{C}-1$ ' and C-1". The ${ }^{13} \mathrm{C}-\mathrm{NMR}$ and DEPT spectra gave a total of twenty-five carbon signals made up of thirteen quarternary carbons including a conjugated carbonyl group ( $\delta$ 186.8), four methine, two methylene, four methyl carbons and two methoxy carbons at $\delta 65.2$ and 60.4. All protonated carbons were assigned by HMQC spectrum and the HMBC spectrum correlations supported the assigned structure. On comparison with literature values, the compound was identified as $\beta$-mangostin (2) previously reported to occur in a number of Garcinia species [1315].

Fuscaxanthone C (3) was isolated from the methanol extract of as yellow oil easily dissolved in chloroform. The EIMS spectrum showed the molecular ion peak at $\mathrm{m} / \mathrm{z} 438$ which is consistent with the molecular formula $\mathrm{C}_{26} \mathrm{H}_{30} \mathrm{O}_{6}$ and another 24 mass unit higher the compound (2) which clearly indicated the replacement of another hydroxyl group with methoxyl group. A broad prominent band at $3397 \mathrm{~cm}-1$ together with a sharp absorption at $1644 \mathrm{~cm}-1$ indicated for the occurrence of hydroxyl and chelated carbonyl groups in the IR spectrum. The integration of the ${ }^{1} \mathrm{H}-\mathrm{NMR}$ spectrum revealed the existence of thirty protons in agreement with the proposed molecular formula. The ${ }^{1} \mathrm{H}-\mathrm{NMR}$ spectrum displayed the typical characteristic signal of a chelated hydroxyl group in the low field region at $\delta 13.47$ which correlated to $\mathrm{C}-1$ (Table 1). Two isolated aromatic signals at $\delta$ $6.33(\mathrm{H}-4)$ and $6.74(\mathrm{H}-5)$ were observed and this implies that both aromatic rings of the xanthone skeleton are pentasubstituted made up a hydroxyl, three methoxyl and two prenyl side chains. The three methoxyl groups occurred at $\delta$ $3.90\left(\mathrm{OCH}_{3}-3\right), 3.96\left(\mathrm{OCH}_{3}-6\right)$ and $3.79\left(\mathrm{OCH}_{3}-\right.$ 7 ) as three sharp singlets. The rest of the signals are due to the prenyl side chains with a set of overlapping triplets at $\delta 5.25(J=4.6 \mathrm{~Hz})$ attributed to the vinylic protons $\mathrm{H}-2$ ' and $\mathrm{H}-2$ ", two sets of doublets at $\delta 3.36(J=6.9 \mathrm{~Hz})$ and $\delta$ $4.14(J=6.9 \mathrm{~Hz})$ due to the methylene groups at $\mathrm{H}-1$ ' and $\mathrm{H}-1$ ", a six protons singlet at $\delta 1.67$ together with two signals of three protons singlet at $\delta 1.79$ and 1.84 were attributed to four methyl groups at position C-5', C-5", C-4' and C-4", respectively. The assignment of the substituents to the two aromatic rings was deduced from interpretation of the HMBC correlation spectrum. The HMBC spectrum showed the long-range correlations of hydroxyl group to carbons at $\delta 103.5(\mathrm{C}-9 \mathrm{a}), \delta 111.2(\mathrm{C}-2)$ and $\delta$ 159.7 (C-1), hence confirmed the position of hydroxyl group at $\mathrm{C}-1$. The position of the three methoxyl groups were further confirmed through the cross peak correlations of proton signals at $\delta$ $3.90\left(\mathrm{OCH}_{3}-3\right), \delta 3.96\left(\mathrm{OCH}_{3}-6\right)$ and $\delta 3.79$ $\left(\mathrm{OCH}_{3}-7\right)$ to their respective aromatic carbons in the xanthone skeleton at C-3 $(\delta 163.8), \mathrm{C}-6(\delta$ $158.8)$ and $\mathrm{C}-7$ ( $\delta$ 144.4). Based on these spectral data and comparison with literature reports, the structure of the compound was established as fuscaxanthone $\mathrm{C}(3)$ previously isolated and identified from Garcinia fusca [16].

The three extracts and two of the reported compounds were tested for their antibacterial and antifungal activities against seven strains of bacteria and a fungus Candida albican by disc diffusion method [10] in comparison with standard drugs tetracycline and ampicillin (10 $\mu \mathrm{g} / \mathrm{disc}$ ) for the antibacterial activity and nystatin (100 IU/disc) for the antifungal activity. Amongst the sample tested, $\alpha$-mangostin (1) exhibited potent activity with inhibition zone on the growth of $B$. subtilis, B. cereus, $S$. typhimurium and $S$. aureus diameter of 16,20 , 17 and $20 \mathrm{~mm}$, respectively. In comparison, $\beta$ mangostin (2) only exhibited moderate inhibition towards these three bacterial strains and from structural point of view this may be due to the loss of a hydroxyl group. Both compounds failed to exhibit any inhibition on the growth of E. coli, $K$. pneumonia and $C$. albican. The most significant cytotoxic activity against human breast adenocarcinoma cell line (MCF7) with $\mathrm{IC}_{50}$ values of $12.48 \mu \mathrm{g} / \mathrm{ml}$ and $28.42 \mu \mathrm{g} / \mathrm{ml}$ were exhibited by both $\alpha$-mangostin (1) and $B$ mangostin (2), respectively. This result is in good agreement with previous study in which $\alpha$ mangostin (1) exhibited in vitro cytotoxic effect against MCF7 at slightly lower $\mathrm{IC}_{50}$ value of $10.5 \mu \mathrm{g} / \mathrm{ml}$ and the growth inhibition was reported due to apoptosis.(Ahmat et al., 2010). The prenyl group in $\alpha$-mangostin (1) is considered to be implicated in the internalization into the cell, which in turn leads to interaction with the signal transduction molecules and the proteins involved in mitochondria permeability transition. As expected, B-mangostin (2) also 
displayed good cytotoxic effect but not as potent as $\alpha$-mangostin (40) and this may be due loss of one of the hydroxyl groups. Compounds (1) and (2) were also reported to exhibit strong cytotoxic activity when tested against HT29 cell line with $\mathrm{ED}_{50}$ values of $1.7 \mathrm{mg} / \mathrm{ml}$ for both [15]. The cytotoxic activity of the crude extracts and pure compounds are summarized in Table 3. Free radical DPPH savenging activity was conducted on the crude extracts and two of the isolated compounds and compared with natural antioxidant $\alpha$-tocopherol. Unfortunately the extracts, $\alpha$-mangostin and $\beta$-mangostin exhibited weak DPPH free radical scavengers with $\mathrm{IC}_{50}$ vlues more than $500 \mu \mathrm{g} / \mathrm{ml}$. Due to limited amount of fuscaxanthone $\mathrm{C} \mathrm{(3)}$ isolated, the test using this compound was not carried out.

\section{CONCLUSION}

$\alpha$-Mangostin, $\beta$-mangostin, fuscaxanthone $\mathrm{C}$ and the commom stigmasterol were isolated and spectroscopically identified from the stem bark extracts of Cratoxylum arborescens. $\alpha$ Mangostin displayed strong antibacterial activity against four species of bacteria with inhibition zone range from $16-20 \mathrm{~mm}$ and prominent cytotoxic activity against MCF7 cell line with $\mathrm{IC}_{50}$ value of $12.48 \mu \mathrm{g} / \mathrm{ml}$. However, the compounds were inactive when tested for antioxidant activity.

\section{ACKNOWLEDGEMENTS}

We wish to express our sincere thanks to Universiti Putra Malaysia for the facilities and Government of Malaysia for providing financial support under the RUGS program ()5-01-090807RU).

\section{REFERENCES}

1. Robson, N.K.B. (1974). Hypericaceae: In flora Malesiana, 8: 129.

2. Wong, K.M. (1995). Hypericaceae, In: Tree Flora of Sabah abd Sarawak, Vol 1, Sabah Forestry Department, FRIM \& Sarawak Forestry Department, Kuala Lumpur, pp. 219-226.

3. Boonnak, N., Karalai, C., Chantrapromma. S., Ponglimanont C., Fun, H.K., Kanjana-Opas, A., and Laphookhieo, S. (2006). Bioactive prenylated xanthones and anthraquinones from Cratoxylum formosum ssp. pruniflorum. Tetrahedron. 62: 885-8859.

4. Mahabusarakam, W., Nuangnaowarat, W., and Taylor, W.C. (2006). Xanthone derivatives from Cratoxylum cochichinense roots. Phytochem. 67: 470-474.

5. Wong, T.M. (1982). A Dictionary of Malaysian Timbers, No. 30, Malaysian Forest Records, Forest Research Institute Malaysia, Kuala Lumpur, pp. 201.

6. Nguyen, L.H.D., and Harrison, L.J. (1998). Triterpenoid and xanthone constituents of Cratoxylum cochinchinense. Phytochem. 50: 471-476.

7. Iinuma, M., Tosa, H., Ito, T., Tanaka, T., and Madulid, D.A. (1996). Two xanthones from roots of Cratoxylum formosanum. Phytochem. 42: 1195-1198.

8. Ee, G.C.L., Jong, V.Y.M., Sukari, M.A., Lee, T.K., and Tan, A. (2010). Anthraquinones from Cratoxylum arborescens (Guttiferae). Pertanika J. Sci. Technol. 18: 77-81.

9. Kijjoa, A., Jose, M., Gonzalez, T.G., Pinto, M.M.M., Damas, A.M., Mondranondra, I.O., Silva, A.M.S., and Herz, W. (1998). Xanthones from Cratoxylum maingayi. Phytochem. 49: 2159-2162.

10. Rojas, R., Bustamante, B., Bauer, J., Fernandez, I., Alban, J., and Lock, O. (2003). Antimicrobial activity of selected Peruvian medicinal plents. J. Ethnopharma, 88: 199-204.

11. Mosman, T. (1983). Rapid colorimetric assay for cellular growth and survival: application to proliferation and cytotoxicity assays. J Immuno. Methods. 65: 55-63.

12. Gopalakrishnan, G., Banumathi, B. and Suresh, G. (1997). Evaluation of the antifungal activity of natural xanthones from Garcinia mangostana and their synthetic derivatives. J. Nat. Prod. 60: 519-524.

13. Yates, P. and Stout GH (1980). The structure of mangostin, J. Am. Chem. Soc., 80: 1670-1691. 
14. Likhitwitayawuid, K., Phadungcharoen, T., and Krungkrai, J. (1998). Antimalarial xanthones from Garcinia cowa. Planta Medica, 64: 70-72.

15. Han, A.R., Kim, J.A., Lantvit, D.D., Kardono, L.B., Riswan, S., Chai, H., Carcache de Blanco, E.J. Farnsworth, N.R., Swanson, S.M., and Kinghorn, A.D. (2009). Cytotoxic xanthone constituents of the stem bark of Garcinia mangostana (mangosteen). J. Nat. Prod. 72: 2028-2031.

16. Ito, C., Itoigawa, M., Takakura, T., Ruangrungsi, N., Enjo, F., Tokuda, H., Nishino, H. and Furukawa, H. (2003). Chemical constituents of Garcinia fusca: structure elucidation of eight new xanthones and their cancer chemopreventive activity. J. Nat. Prod. 66: 200-205. 